\title{
An Interview Report on Users' Perception about the Usability Performance of a Mobile E-Government Application
}

\author{
https://doi.org/10.3991/ijim.v13i10.11286 \\ Azham Hussain $(\bowtie)$ \\ University Utara Malaysia, Sintok, Kedah, Malaysia \\ azhamh 78@yahoo.com \\ Emmanuel O.C. Mkpojiogu \\ Veritas University, Abuja, Nigeria \\ Norzila Ishak, Nurhidayah Mokhtar, Zhamri Che Ani \\ University Utara Malaysia, Sintok, Kedah, Malaysia
}

\begin{abstract}
Mobile governance enables citizens to comfortably do business with government anywhere, any time. This provides an enriching experience to users as they use these platforms in their convenience and with comfort. MyEG Services Berhad ("MyEG") is a concessionaire for Malaysian ElectronicGovernment ("E-Government") MSC Flagship Application. MyEG manages the electronic channel that offers services from various Government agencies to the Malaysian citizens and businesses. The MyEG developed a mobile application that can be used to check summons, pay summons, renew road-tax and renew auto insurance. In this study, a usability assessment was done using interview approach to examine the experience of users (with regard to usability) of the mobile application. The interview was carried out after participants engaged and interacted with the application in some task's scenarios. The assessment was done at Jabatan Technology Maklumat and Komunikasi, Polytechnic Seberang Perai, with 15 volunteers who consisted of lecturers and students. The findings showed that overall the application was perceived usable and also enriched the experience of participants. However, there were some improvements that should be implemented in the area of findability to further improve on users' satisfaction and felt experience.
\end{abstract}

Keywords-E-government, interview approach, mobile experience; usability performance, user perception

\section{Introduction}

Mobile governance enables citizens to comfortably do business with government anywhere, any time. This thus provides an enriching experience to users. MyEG Services Berhad ("MyEG") is a concessionaire for Malaysian Electronic-Government 
("E-Government") MSC Flagship Application. MyEG manages the electronic channel that offers services from various Government agencies to the Malaysian citizens and businesses. The MyEG developed a mobile application that is used to check summons, pay summons, renew road-tax and renew auto insurance. The mobile MyEG app has gone through a complete overhaul with the provision of new features and functionalities. The new improvements offer users accessibility to a collection of egovernment transactions. The users are required to first login unto the MyEG app to gain access for the services provided by the app. These services are inter alia: renewal of road tax, renewal of auto insurance, checking and payment of PDRM summonses, checking and payment JPJ summonses, and the checking of delivery status for requested MyEG services. With the updated mobile app, customers can quickly carry out their e-government transactions at any time and any place with ease, convenience and comfort [1-15].

\section{Methods}

Fifteen (15) volunteers were recruited for this study. These participants were made to first do some tasks on the MyEG app and then were thereafter interviewed. The think aloud protocol was employed. A facilitator coordinated the entire assessment [16-27].

There were five tasks tested in the test:

- Install the application

- Login into the application

- Customize user profile

- Check PDRM summonses

- Make a payment for PDRM summonses

The task scenarios are as follows [28-39]:

Task 1 Scenario: Install the application

Instructions are as follows: Using android phone, try to install MyEG app.

Description: This task requires a participant to install the MyEG app using an android phone. Users success rates in accomplishing this task will be measured as well as the time they took for the installations process. The steps involved include:

- The participant should find the "Play Store" in the android phone, and then type MyEG at the Google Play search engine. After that, the participant should select the install button for the installation process.

- If the installation process is success, the participant will see the open button at the application.

- The user should login into the application.

Task 2 Scenario: Login into the application

Instruction: From the home page of android phone, try to login into the MyEG app using the given ID and password. ID: ayumiesz; and Password: sonicz; the steps involved include: 
- After installing the MyEG app, the participant should try to login into the application using the information given, that is, he/she should key in his/her username and password and then click on the login button;

- See the error message if any exits.

Task 3 Scenario: Customize user profile

Instruction: In login status, try to update user profile for item address and item phone number based on the information below:

Phone number: 013 - 3425874

Postcode: 13800

City: Butterworth

State: Pulau Pinang

Address: No 234, Taman Saujana, Jalan Keramat

The steps involved include:

- In login status, participant is required to click menu function and then choose edit profile;

- At the edit profile, participant is required to update information based on the task instructions and then save the changes.

Task 4 Scenario: Check PDRM Summonses

Instruction: In login status, try to check PDRM summonses based on the ID: 840512105386

After the list of summonses is viewed at the android phone screen, the participant/tester must speak aloud on how many summonses were viewed. The steps involved include:

- In login status, at the home page, participant is required to click check \& pay PDRM Summons function and then insert the given ID Number;

- After inserting the ID Number, participant then clicks the button Check Summons. If the ID Number have summons, then a list of summons will be viewed.

Task 5 Scenario: Make a payment for PDRM Summonses.

Instruction: In login status, select one PDRM summons and make payment for that summons using the information below to fill payment information.

Card Type: Visa

Card Expiry Date: $\mathrm{MM}=12$ and YYYY $=2019$

Card Number: 4786704000080233

Security Code: 011

Card Holder Name: Norzila Ishak

Card Issued By: Bank Islam Malaysia Berhad

Tick authorized and then submit the payment.

The steps involved include:

- After inserting the ID Number, click the button Check Summons. If the ID Number have summons, a list of summons will be viewed

- Tick one summons and make payment. A click of the button pays 1 summons 
- After that, confirm details will be viewed. Participants are required to click proceed to payment button and then payment details will be viewed

- Participants then make payment using credits card. To make payment, participants click on credit cards (Master/Visa) button and then the credit card form details will be viewed

- Participants need to fill the credit card information using the given information at task

- Next, participants click the authorized button and then submit the form

- The MyEG app will process the information for the validation of card details

Some equipment and materials were used to support the usability evaluation:

- Android mobile devices: Android mobile devices were used to carry out the tasks on the MyEG app. Participants used these devices to carry out the evaluation.

- Mobile device camera: Mobile device camera was used by the facilitator in capturing and understanding the users' interaction by capturing their facial expressions.

- Internet connectivity: this was provided by Celcom First Gold Plus CBS to make the task of app installation successful (task 1).

- Written instructions: these written instructions provided guideline for participants as they perform their tasks.

The ISO/IEC 9241-11 standard served as a guide for the evaluation of the app. The standard posits that usability is "the extent to which a product can be used by specified users to achieve specified goals with effectiveness, efficiency and satisfaction in a specified context of use". Effectiveness: The accuracy and completeness with which specified users achieve specified goals in particular environments and contexts. Efficiency: The resources expended in relation to the accuracy and completeness with which users achieve goals in a given context of use. Satisfaction: The comfort and acceptability of use. It is the positive feelings that users have or show toward a product after using or interacting with it. The interview was used to capture users' perception about the usability of the MyEG application [40-50]. 


\section{Results and Discussion}

The following table displays summary of the result of the interview conducted.

Table 1. Summary of Findings from the Interview

\begin{tabular}{|c|}
\hline Question 1: What are your overall impressions about the application? \\
\hline $\begin{array}{l}\text { With regard to this question, the feedback from all the respondents was that the application was very useful } \\
\text { and easy to use. They all concurred that they can check summons, pay summons, and renew road tax by } \\
\text { the click of the hand. Indirectly this application saves them time and energy, and so they do not need to } \\
\text { travel to JPJ, or Police Station to pay summons or to renew road tax. }\end{array}$ \\
\hline Question 2: What are the things you like best about the application? \\
\hline $\begin{array}{l}\text { Most of the respondents liked the simplicity of the application's user interface and the ease of use of the } \\
\text { application. }\end{array}$ \\
\hline Question 3: What are the things you like least about the application? \\
\hline $\begin{array}{l}\text { Most of the respondents do not have any things that they do not like about the application; however there } \\
\text { was one candidate who suggested that the main menu should be reconstructed in terms of arranging the } \\
\text { menu in grid form, and providing each menu an icon so that it will be more user friendly. He also } \\
\text { complained about the user profile interface, that users cannot scroll down easily when they are filling up } \\
\text { their details. }\end{array}$ \\
\hline Question 4: Given scale 1-10, how would you rate this application? \\
\hline
\end{tabular}

Findability issue was however observed. There were a few participants who failed to follow their given task accordingly, especially task 3 , because they failed to find the update menu. Overall, the results of the study can be summed in the following themes, namely, performance, learning, interface, and end-user satisfaction. Performance: It was found that the performance of the application in term of application installation, application response, and site information depended on the speed of the mobile data or Wi-Fi used by the respondents. The respondents perceived that they were satisfied with the performance of the application. Learning: In terms of learning, it was found that most of the respondents perceived that they were able to follow and carry out the tasks accordingly, however, there were a few of them that felt that they had trouble doing some tasks, particularly carrying out task 3, where they were required to customize the user profile, the respondents seem to have had trouble in finding the user profile menu and updating their given user profile details. Interface: with regard to the user interface, it was found that most of the participants were satisfied with the user interface. They found that the user interface was simple, attractive, and that there was the use of appropriate symbols. They perceived that the interface was user friendly and easy to use. However, the user profile interface seems to require some modifications as expressed by some participants. End-user satisfaction: regarding end-user satisfaction, all the participants felt satisfied with the application and opined that it is easy to use and that the functions of the application is straight forwards [47-53].

Recommendations: The study proffers a couple of recommendations that can be used to further improve the experience and satisfaction of users for the application: 
- Re-arrange the main menu in grid form so that it is more user friendly. Add more appropriate symbol/icon in the menu

- Re-locate the user profile menu so that it is easier to find

- Make the edit user profile interface scrollable when used in filling the details so that users can scroll up and down easily

- Change the colour of the edit button in the edit user profile interface so that it will be more noticeable to improve findability. This is because when users want to update their details, they must press the button.

\section{Conclusion}

The study employed interview approach to assess the usability of a mobile egovernment application (MyEG app). The assessment was meant to capture the user experiences of the application. The ISO 9241-11 standard was used to guide the assessment. The result of the assessment revealed that overall the interface of the mobile application was usable and offered users enriching experience. However, there were some issues findability that demands attention and improvement in subsequent updates of the application. To improve findability and user experience, the main menu needs to be re-arranged and more appropriate symbol/icon need to be added in the menu. The user profile menu needs to be relocated to make it easier to find. The edit user profile interface needs to be made scrollable when used for filling user details so that users can scroll up and down easily. The color of the edit button in the edit user profile interface need to be changed so that it will be more noticeable and findable.

\section{$5 \quad$ References}

[1] Hussain, A, Mkpojiogu, EOC, Yahaya, NB \& Bakar, NZBA (2018), A mobile usability assessment of an m-shopping app. Journal of Advanced Research in Dynamical and Control Systems (JARDCS) 10 (SI), 1212-1217. https://doi.org/10.1063/1.5055455

[2] Gündüz, F \& Pathan, ASK (2013), on the key factors of usability in small-sized mobile touch-screen application. Int. J. Multimed. Ubiquitous Eng, 8(3), 115-138.

[3] Kaikkonen, A, Kekäläinen, A., Cankar, M, Kallio, T \& Kankainen, A (2005), Usability testing of mobile applications: A comparison between laboratory and field testing. Journal of Usability Studies, 1(1), 4-16.

[4] Hussain, A, Mkpojiogu, EOC, Jamalsse, A \& Mohammed, RA (2018), Grab mobile app: a UX assessment on mobile devices. Journal of Advanced Research in Dynamical and Control Systems (JARDCS) 10 (SI), 1233-1238.

[5] Liu, F (2008), Usability Evaluations on Websites. School of Art \&Design, Wuhan University of Technology, Wuhan, Hubei Province, p: 141.

[6] Dumas, JS \& Redish, J (1999), A practical Guide to Usability Testing. Intellect Ltd, UK, US.

[7] Srivasta, J, Cooley, R, Deshpande, M \& Tan, PN (2000), Web Usage Mining: Discovery and Application of Web Usage Pattern from Web Data. Department of Computer Science and Engineering, University of Minnesota. https://doi.org/10.1145/846183.846188 
[8] Mkpojiogu, EOC, Hussain, A \& Hassan, F (2018), A systematic review of usability quality attributes for the evaluation of mobile learning applications for children. ICAST 2018, AIP Conf. Proc. 2016 https://doi.org/10.1063/1.5055494

[9] Icela, L (2017), Usability evaluation focused on user experience of repositories related to energy sustainability: A Literature Mapping.

[10] Nayebi, F, Desharnais, JM \& Abran, A (2012), The state of the art of mobile application usability evaluation, 2012 25th IEEE Can. Conf. Electr. Comput. Eng., 1-4. https://doi.org/10.1109/CCECE.2012.6334930

[11] Paz, F \& Pow-Sang, JA (2014), Current Trends in Usability Evaluation Methods: A Systematic Review, 2014 7th Int. Conf. Adv. Softw. Eng. Its Appl., pp: 11-15. https://doi.org/10.1109/ASEA.2014.10

[12] Hussain, A, Mkpojiogu, EOC \& Suleiman, K (2018), A usability testing of a mobile print shop booking and design application. Journal of Advanced Research in Dynamical and Control Systems (JARDCS) 10 (SI), 1359-1365.

[13] Holzinger, A (2005), Usability engineering methods for software developers. Communications of the ACM, 48(1), 71-74. https://doi.org/10.1145/1039539.1039541

[14] Molich, R, \& Wilson, C (2008), Tips and tricks for avoiding common problems in usability test facilitation. CHI'08 extended abstracts on Human factors in computing systems. ACM, pp: 2379-2382. https://doi.org/10.1145/1358628.1358689

[15] Hussain, A, Mkpojiogu, EOC, Suleiman, K \& Alhussian, H (2018), A heuristic evaluation of a mobile print and design shopping application. Journal of Advanced Research in Dynamical and Control Systems (JARDCS) 10 (SI), 1457-1462. Buchanan, S, \& Salako, A (2009), Evaluating the usability and usefulness of a digital library. Library Review, 58(9), 638-651. https://doi.org/10.1108/00242530910997928

[16] Rubin, J \& Chisnell, D (2008), Handbook of Usability Testing: How to Plan, Design, and Conduct Effective Tests. Canada: John Wiley \& Sons, Inc.

[17] Hussain, A, Mkpojiogu, EOC, Abduljabbar, AM \& Almadhagi, AHG (2018). UUM mobile for students: a usability evaluation on two mobile OS platforms. Journal of Advanced Research in Dynamical and Control Systems (JARDCS) 10 (SI), 1514-1519.

[18] Gündüz, F \& Pathan, ASK (2012), Usability improvements for touch-screen mobile flight booking application: A case study. 2012 International Conference on Advanced Computer Science Applications and Technologies (ACSAT), IEEE, pp: 49-54. https://doi.org/10. 1109/ACSAT.2012.9

[19] Dillon, A (2002), beyond usability: process, outcome and affect in human-computer interactions. Canadian Journal of Library and Information Science.

[20] Mkpojiogu, EOC \& Hussain, A (2018), assessing the influence of self-reported requirements importance on the perceived quality of proposed software products. ICAST 2018, AIP Conf. Proc. 2016, 020091, https://doi.org/10.1063/1.5055493

[21] Ahmad, N, Boota, MW \& Masoom, AH (2014), Smart Phone Application Evaluation with Usability Testing Approach, J. Softw. Eng. Appl., 7(12), 1045. https://doi.org/10.4236/jsea.2014.712092

[22] Brown, ME \& Hocutt, DL (2015), Learning to Use, Useful for Learning: A Usability Study of Google Apps for Education, J. Usability Stud., 10 (4), 160-181.

[23] Hussain, A, Mkpojiogu, EOC, Isse, AJ \& Mohammed, RA (2018), Grab mobile application: a usability evaluation. ICAST 2018, AIP Conf. Proc. 2016, 020054, https://doi.org/10.1063/1.5055456

[24] ISO 9241-11 (1998), Ergonomic requirements for office work with visual display terminals (vdts) - part 11: Guidance on usability. ISO Standard 9241-11: 1998. International Organization for Standardization. 
[25] Hussain, A, Mkpojiogu, EOC, Yahaya, NB \& Bakar, NZBA (2018), A mobile usability assessment of carousell mobile app. ICAST 2018, AIP Conf. Proc. 2016. 020053, https://doi.org/10.1063/1.5055455

Bartek, V \& Cheatha, MD (2003), Experience Remote Usability Testing, Part 2: Examine the Benefits and downside of Remote Usability Testing. http://www.mendeley.com/rese arch/experience-remote-usability-testing-part-2-examine-benefits-downside-remote-usabilitytesting/

[27] Hussain, A, Mkpojiogu, EOC, Abduljabbar, AM \& Almadhagi, AHG (2018), A usability evaluation of UUM mobile for student's app on IOS and android platforms. ICAST 2018, AIP Conf. Proc. 2016, 020052, https://doi.org/10.1063/1.5055454

[28] Chau, P. Cole, M, Massey, AP, Montoya-Weiss, M \& O'Keefe, RM (2002), Cultural differences in consumer's online behaviors. Commun. ACM, 45(10), 45-50. https://doi.org/10. $\underline{1145 / 570907.570911}$

[29] Hussain, A, Mkpojiogu, EOC \& Hassan, F (2018), Usability dimensions and sub-dimensions for the evaluation of m-learning apps for children: A review. International Journal of Engineering \& Technology (IJET) 7 (3.20), 291-295. https://doi.org/10.14419/ijet.v7i3.20.19168

[30] Forsell, C \& Johansson, J (2010), An heuristic set for evaluation in information visualization. Proceedings of the International Conference on Advanced Visual Interfaces, ACM, pp: 199206. https://doi.org/10.1145/1842993.1843029

[31] Krippendorff, K (2004), Content Analysis: An introduction to its methodology, (Sage Publications Inc., United States, 2004).

[32] Gehrke, D \& Turban, E (1999), Determinants of successful website design: Relative importance and recommendations for effectiveness, Proc. 32nd Hawaii Int. Conf. System Sciences.

[33] Harrison, R, Flood, D \& Duce, D (2013), Usability of mobile applications: Literature Review and Rationale for A New Usability Model, 1-16. https://doi.org/10.1186/2194-0827-1-1

[34] Hussain, A \& Mkpojiogu, EOC (2015), An application of the ISO/IEC 25010 standard in the quality-in-use assessment of an online health awareness system, J. Teknol., 77(5) 9-13. https://doi.org/10.11113/jt.v77.6107

[35] El-Gayar, O, Timsina, P, Nawar, N, \& Eid, W (2013), Mobile applications for diabetes selfmanagement: Status and potential, J. Diabetes Sci. Technol., 7(1), 247-262. https://doi.org/10.1177/193229681300700130

[36] Naismith, L (2004), Literature review in mobile technologies and learning, NESTA Futur. Ser. ; Rep. 11, p: 44.

[37] Hussain, A, Abd Razak, MNF, Mkpojiogu, EOC \& Hamdi, MMF (2017), UX evaluation of a video streaming application with teenage users. Journal of Telecommunication, Electronic \& Computer Engineering (JTEC), 9 (2-11), 129-131.

[38] Naslund, JA, Aschbrenner, KA, Marsch, LA \& Bartels, SJ (2016), The future of mental health care: Peer-To-peer support and social media, Epidemiol. Psychiatr. Sci., 25 (2), 113122. https://doi.org/10.1017/S2045796015001067

[39] Hussain, A, Isam, M \& Mkpojiogu, EOC (2017), A UX assessment of a mobile recommender app for household electrical energy savings. Journal of Telecommunication, Electronic \& Computer Engineering (JTEC), 9 (2-11)

[40] Joo, S, Lin, S \& Lu, K (2011), A Usability Evaluation Model for Academic Library Websites: Efficiency, Effectiveness and Learnability, J. Libr. Inf. Stud., 9(2), 11-26.

[41] Toribio-Guzmán, JM, García-Holgado, A, Pérez, FS, García-Peñalvo, FJ \& Martín, MAF (2016), Study of the Usability of the Private Social Network SocialNet using Heuristic Evaluation, Proc. XVII Int. Conf. Hum. Comput. Interact. - Interacción '16, pp: 1-5. https://doi.org/10.1145/2998626.2998674 
[42] Hussain, A, Mkpojiogu, EOC \& Jasin, NMD (2017), Usability metrics and methods for public transportation applications: a systematic review. Journal of Engineering Science and Technology (JESTEC), Special Issue on ISSC'16, 4, 98-105.

[43] Chiang, KP \& Dholakia, RR (2003), Factors Driving Consumer Intention to Shop Online: An Empirical Investigation, Journal of Consumer psychology, 13(1\&2), 177-183. https://doi.org/10.1207/S15327663JCP13-1\&2 16

[44] Hussain, A, Isam, M \& Mkpojiogu, EOC (2017), A UX assessment of a mobile recommender app for household electrical energy savings. Journal of Telecommunication, Electronic \& Computer Engineering (JTEC), 9 (2-11)

[45] Bangor, A, Kortum, P \& Miller, J (2009), determining what individual SUS scores mean: Adding an adjective rating scale. Journal of Usability Studies, 4(3), 114-123.

[46] Hussain, A, Mkpojiogu, EOC, Musa, J \& Mortada, S (2017), A user experience evaluation of amazon kindle mobile application. Proceedings of the $2^{\text {nd }}$ International Conference on Applied Science and Technology (ICAST'17), Kedah, Malaysia. AIP Conference Proceedings 1891 (1), 020060, https://doi.org/10.1063/1.5005393

[47] Nielsen, J (1993), Usability Engineering, Academic Press, United States. https://doi.org/10.1016/B978-0-08-052029-2.50007-3

[48] Hussain, A, Mkpojiogu, EOC, Fadzil, NM \& Hassan, NM (2017), The UX of amila pregnancy on mobile device. Proceedings of the $2^{\text {nd }}$ International Conference on Applied Science and Technology (ICAST'17), Kedah, Malaysia. IP Conference Proceedings 1891 (1), 020061, http://doi.org/10.1063/1.5005394. https://doi.org/10.1063/1.5005394

[49] Kiseol, Y \& Hye-Young, K (2012), Mobile shopping motivation: an application of multiple discriminant analysis, International Journal of Retail \& Distribution Management, 40(10), 778-789. https://doi.org/10.1108/09590551211263182

[50] Hussain, A, Mkpojiogu, EOC, Abubakar, H \& Hassan, HM (2017), The usability evaluation of mudah.my on mobile device. Proceedings of the $2^{\text {nd }}$ International Conference on Applied Science and Technology (ICAST'17), Kedah, Malaysia. AIP Conference Proceedings 1891 (1), 020058; https://doi.org/10.1063/1.5005391

[51] Ferré, X, Juristo, N, Windl, H \& Constantine, L, Usability engineering Usability Basics, IEEE Softw., 18 https://doi.org/10.1109/MS.2001.903155

[52] Hussain, A, Mkpojiogu, EOC, Jamaludin, NH \& Moh, STL (2017), A usability evaluation of Lazada mobile application. Proceedings of the $2^{\text {nd }}$ International Conference on Applied Science and Technology (ICAST'17), Kedah, Malaysia. AIP Conference Proceedings 1891 (1), 020059, http://doi.ord/10.1063/1.5005392 https://doi.org/10.1063/1.5005392

[53] Limayem, M, Khalifa, M \& Frini, A (2000), what make consumer buy from internet? A Longitudinal study of online shopping. IEEE Transactions on Systems, Man, and CyberneticsPart A: Systems and Humans, 30(4). https://doi.org/10.1109/3468.852436

\section{Authors}

Azham Hussain is the Associate Professor of Software Engineering at School of Computing, University Utara Malaysia, Kedah, Malaysia. He is the founder of $\mathrm{Hu}-$ man-Centered Computing Research Group, which is affiliated with the Software Technology Research Platform Center at School of Computing, University Utara Malaysia. Azham Hussain is a member of the US-based Institute of Electrical and Electronic Engineers (IEEE), and actively involved in both IEEE Communications and IEEE Computer societies. 
Emmanuel O.C. Mkpojiogu is a Lecturer at Department of Computer and Information Technology, Veritas University, Abuja, Nigeria. Currently, he is a PhD student at School of Computing, University Utara Malaysia. The research area is User Experience, Human Computer Interaction and Software Engineering. He has published many articles in reputable Scopus indexed journals.

Norzila Ishak is a lecturer at Department of Information Technology and Communication, Politeknik Seberang Perai, PermatangPauh, Penang. Her research focus on Human Computer Interaction and User Experience.

Nurhidayah Mokhtar is a lecturer at Department of Information Technology and Communication, Polytechnic Seberang Perai, PermatangPauh, Penang. She has completed her master's in information technology and looking forward to further to $\mathrm{PhD}$ in Human Computer Interaction or Software Requirement for mobile.

Zhamri Che Ani is a Lecturer at School of Computing, University Utara Malaysia, Kedah, Malaysia. His research interest is on Software Metrics, Software Quality and other artificial intelligent research area. He published many article in various indexed journal.

Article submitted 2019-05-09. Resubmitted 2019-07-04. Final acceptance 2019-07-17. Final version published as submitted by the authors. 